\title{
EFEKTIVITAS PELAKSANAAN E-PROCUREMENT DALAM PENGADAAN BARANG DAN JASA
}

\author{
Muhammad Mujtaba Habibi, Sri Untari \\ Jurusan Hukum dan Kewarganegaraan, Universitas Negeri Malang \\ Jl. Semarang No.5 Malang \\ email:m.mujtaba.fis@um.ac.id
}

\begin{abstract}
This study aims to analyze the effectiveness of the implementation of E-procurement in the procurement of goods and services in the city government of Malang, and analyze the obstacles in its implementation. The research method used is descriptive qualitative. Data collection techniques are done by documentation observation and interview. Data analysis uses an interactive model. The results of the study showed that in general the implementation of e-procurement in the procurement of goods and services in the City Government of Malang effectively as evidenced by the implementation of a transparent and accountable tender so that it was possible for each company to take part in the tender. The obstacles in implementing e-procurement are the existence of dual positions, unsatisfactory human resources and unsupportive infrastructure.
\end{abstract}

Keyword: e-procurement, procurement, goods, services

\begin{abstract}
Abstrak: kajian ini bertujuan untuk menganalisis efektivitas pelaksanaan E-procurement dalam pengadaan barang dan jasa di pemerintah kota Malang, serta menganalisis hambatan pelaksanaannya. Jenis penelitian ini deskriptif kualitatif. Teknik pengumpulan data dengan dokumentasi, observasi dan wawancara. Model interaktif digunakan dalam analisis data. Hasil kajian menunjukkan bahwa secara umum pelaksanaan e-proc di Pemerintah Kota Malang berjalan efektif terbukti dengan pelaksanaan tender yang transparan dan akuntabel sehingga memungkinkan untuk setiap perusahaan mengikuti tender tersebut, selain itu pelaksanaan tender juga sangat mudah dengan memanfaatkan sistem aplikasi. Hambatan dalam pelaksanaan e-procurement yaitu adanya rangkap jabatan, sumber daya manusia yang kurang memenuhi dan prasarana yang kurang mendukung.
\end{abstract}

Kata Kunci:e-procurement, pengadaan, barang, jasa

Penyelenggaraan pemerintahan menuju pemerintahan yang baik (good governance) merupakan sebuah impian dan target yang ingin dicapai oleh sebuah negara khususnya Indonesia. Good governance merupakan sebuah konsep penyelenggaraan pembangunan yang dilakukan oleh pemerintah yang seluruh pelaksanaannya dapat dipertangungjawabkan. Penyelenggaraan tersebut harus melibatkan 3 aktor utama yaitu negara, swasta dan masyarakat dengan tujuan agar terjadi sebuah proses kerjasama dan satu sama lain saling melakukan pengawasan. Prinsip-prinsip Good governance diantarnya adalah keterlibatan masyarakat dalam pengambilan kebijakan yang menghasilkan sebuah keputusan, menjunjung tinggi hakikat hukum, tranparansi dalam setiap penyelenggaraan pemerintahan serta peduli terhadap semua pihak yang membutuhkan pelayanan. Konsep pemerintahan yang bersih dan baik dapat tercapai apabila segala urusan pemerintahan dilaksanakan secara terbuka, partisipasif, responsif dan mematuhi aturan yang berlaku. Good governance dimaknai sebagai tindakan atau perilaku berdasarkan pada aspek nilai dan bersifat mengatur, mempengaruhi masyarakat untuk mengaktualisasikan nilai tersebut dalam kehidupan bermasyarakat. sehingga faktor terpenting demi terwujudnya pemerintahan yang baik adalah perilaku yang berdasarkan pada aturan nilai yang baik.

Salah satu upaya pemerintah Indonesia dalam menuju pemerintahan yang baik dilakukan dengan cara pemanfaatan teknologi dalam setiap pelayanannya. Salah satu pelayanan pemerintah 
yang menerapkan teknologi adalah pengadaan barang serta jasa. Pengadaan tersebut dahulu dilaksanakan secara manual sistem pelelangan tatap muka antara peserta pelelangan dengan panitia. Hal tersebut tentu kurang efisien serta dapat menimbulkan berbagai penyimpangan diantaranya proses tender yang tidak transparan yang memungkinkan adanya kecurangan yaitu berupa suap serta besar kemungkinan terjadi nepotisme dalam prosesnya. Menurut Sucahyo dkk, 2009 dalam udoyono 2012, bentuk penyimpangan dalam pengadaan baik barang maupun jasa secara konvensional memungkinkan adanya permainan harga dan berpeluang untuk terjadi tender arisan dimana oknum peserta lelang akan bekerja sama dengan peserta lainnya dalam proses pelelalangan sehingga pemenang lelang akan diatur sedemikian agar secara bergiliran dapat dimenangkan oleh kelompoknya sendiri. Selain itu juga bentuk penyimpangan yang terjadi sebagai akibat dari adanya pengadaan secara konvensional adalah adanya suap untuk memenangkan salah satu pihak, adanya kompromi untuk melakukan manipulasi harga, mencantumkan spesifikasi yang hanya dapat diperoleh dari 1 perusahaan saja dan pengaturan spesifikasi dan kualitas barang untuk mendapatkan keuntungan.

Pada masa sekarang proses mekanisme dilakukan secara tersistem yang berbasis online yang biasa disebut dengan E-Procurement yang merupakan mekanisme berbasis sistem dalam pengadaan barang khususnya dalam lingkungan pemerintahan (Wijaya dkk, 2010). Tujuan e-procurement adalah agar proses pengadaaan dapat dilaksanakan secara transparan dan mengutamakan adanya prinsip keterbukaan sehingga siapapun dapat bersaing secara bebas dan sehat sehingga kualitas barang dan jasa dalam proses jual-beli tersebut menjadi yang terbaik karena masing-masing penyedia barang akan berusaha untuk memberikan barang terbaiknya.

Mekanisme e-procurmenent menjadikan proses jual beli dapat dilakukan secara efisien diantaranya pemilik barang dan jasa tidak lagi hadir di kantor pemerintahan untuk mengikuti proses jual beli secara tatap muka. Selain itu proses e-procurement membantu dalam proses kontrol dan evaluasi pelaksanaan pengadaan yang dapat menjadi salah upaya dalam mengatasi KKN karena semuanya dilakukan secara transparan dengan tujuan akhir agar sebuah pemerintahan mampu mewujudkan clean and good gover- nance. Menurut Neupane dkk (2014) e-proc dapat mengurangi perilaku korup dalam mekanisme proses pengadaan di lingkungan publik. Hal tersebut juga memiliki hubungan yang positif dengan konsep untuk mengurangi kekuatan monopoli oleh kelompok tertentu dan asimetri informasi dan transparansi dan akuntabilitas yang berkontribusi terhadap berkurangnya kemungkinan terjadi korupsi dalam pengadaan barang publik.

Pemerintah Kota Malang mempunyai peraturan sebagai dasar dalam pengadaan barang serta jasa yaitu Perwal kota Malang No. 13 Thn 2012 tentang Tata Cara Pengadaan Barang dan serta jasa secara elektronik. Kebijakan tersebut diberlakukan pada semua organisasi perangkat daerah (OPD) pemerintah Kota Malang dalam setiap pengadaan yang dilakukan secara rutin setiap tahunnya. Transaksi yang dilakukan dengan berbasis e-proc bertujuan agar terhindar dari segala bentuk penyimpangan yang menyebabkan terjadinya kerugian dalam setiap pengadaan baik barang maupun jasa yang dilakukan oleh pemerintah Kota Malang. Berdasarkan penjelasan diatas menarik untuk dilakukan kajian terhadap efektifitas pelaksanaan e-procurement dalam pengadaan barang serta jasa di lingkungan pemerintah kota Malang

\section{E-PROCUREMENT}

Sistem e-procurement yang digunakan terhadap pengadaan baik barang maupun jasa di lingkungan kementerian dan lembaga telah dilakukan semenjak 2010. E-Proc adalah teknologi digital yang terintegrasi dengan website untuk memudahkan dalam proses pengadaan barang diantaranya berupa permintaan barang, pencarian barang, pemesanan barang, kontak kerja dengan penyedia barang serta pembayarannnya. (Turban et al. 2010: 290).E-procurement pada saat ini telah banyak digunakan di lingkungan pemerintahan dan swasta dalam mewujudkan pengadaan yang lebih efisien dan dapat dipertanggung jawabkan. E-procurement merupakan sistem yang terintegrasi terhadap keseluruhan aktivitas pengadaan yaitu berupa penawaran, pemesanan, pembayaran dan pengiriman.

Di dalam Kepres RI No. 54 Th. 2010 yang telah diubah menjadi PP No. 70 Th. 2012 ttg. Pedoman Pengadaan di Pemerintah di jelaskan bahwa e-proc adalah suatu proses pengadaan yang dilakukan dengan cara terintegrasi teknologi 
sesuai dengan ketentuan yang berlaku. Pengertian lain e-Procurement yaitu transaksi secara elektronik (e-Proc) adalah kegiatan jual beli dengan didukung jaringan internet (Willem Siahaya, 2012:80). Dalam Sutedi (2012:254) "E-Proc merupakan sistem pelelangan dalam pengadaan baik barang maupun jasa publik dengan menerapkan teknologi."

\section{TUJUANE-PROCUREMENT}

E-procurement bertujuan untuk memudahkan lembaga atau instansi pemerintahan dalam proses pencarian kebutuhan barang dan jasa yang diawali dengan pencarian spesifikasi barang sampai pada proses pembayaran yang di dalamnya juga terdapat komunikasi langsung secara online antara pembeli dalam hal ini pemerintah dengan penjual (swasta/pihak ketiga) (Sutedi, 2012:258). Dalam Psl 107 Perpres No 70 Th. 2012 menunjukkan bahwa arah tujuan dari e-Proc untuk mewujudkan transparansi dan akuntabilitas, menjaga kenormalan persaingan usaha agar lebih terbuka, mempermudah proses pengawasan dan evaluasi dan Memenuhi kebutuhan secara cepat dalam waktu yang bersamaan

Tujuan dari e-procurement menurut J. E. Demin (ISC)dalam Dimas Aditya (2014) adalah sebagai berikut:

1. Meningkatkan pelayanan terhadap pihak terkait.

2. Mengintegrasikan barang-barang tersedia dengan perusahaan yang menyediakan

3. Mengurangi biaya administrasi dengan cara memesan langsung kepada perusahaan tertentu

4. Mewujudkan persaingan yang bersih dan sehat antar perusahanan penyedia

5. Memudahkan pembeli yaitu dalam hal ini adalah pemerintah dalam menginventaris barang yang sudah dibeli

6. Peningkatan penggunaan SDM

7. Mengurangi proses administrasi yang berbelit belit

Manfaat e-procurement dalam pelaksanaan pengadaan di lingkungan pemerintahan:

1. Pengadaan dapat dilakukan secara terbuka dan menciptakan persaingan yang sehat dan adil

2. Mendorong swasta untuk berpartisipasi dalam pengadaan di lingkungan publik. Selain itu, masyarakat secara mudah mengetahui proses pengadaan tersebut di lingkungannya
3. Semua peserta pengadaan dapat saling mengawasi untuk mencegah terjadinya korupsi mengingat dalam pelaksanaan pengadaannya tidak dilakukan secara tata muka antara penyedia barang dan pemerintah.

4. Memudahkan untuk memperoleh barang maupun jasa yang diperlukan berdasarkan kriteria teknis yang di inginkan;

5. Memberikan kemudahan baik kepada pemerintah maupun penyedia barang karena dilakukan secara online.

6. Penghematan biaya dan waktu.

7. Memudahkan untuk melakukan pertanggungjawaban.

\section{METODE PELAKSANAAN E-PROCURE- MENT}

Dalam pelaksanaan program e-Proc ada beberapa metode pelaksanaan seperti yang disampaikan oleh Willem (2012: 81) yaitu:

\section{1. e-Tendering}

Proses penawaran penyediaan barang secara elektronik yang dapat diikuti oleh seluruh perusahaan pemilik barang dan jasa

2. e-Bidding

Proses penyampaian informasi secara elektronik dari perusahaan penyedia.

3. e-Catalogue

Sebuah sistem elektronik yang berisi informasi daftar barang, jenis barang, kriteria teknis dan nominal harga barang dan jasa dari berbagai macam perusahaan penyedia.

4. e-Purchasing

Serangkaian mekanisme pembelian sekaligus pembayaran barang maupun jasa menggunakan menu e-Catalogue"

Secara rinci berikut tahapan pelaksanaan $e$ procurement

1. Identifikasi Kebutuhan

Tahap pertama adalah pembeli melakukan proses identifikasi mengenai kebutuhan barang dan jasa. Tujuan dari proses ini untuk memberikan gambaran mengenai barang dan jasa yang akan di masukkan di dalam sistem.

2. Persetujuan Pembeli dan perusahaan penyedia barang

Setelah mengetahui barang atau jasa yang dibutuhkan, tahapan berikutnya adalah menentukan pihak ketiga penyedia.Perusahaan penyedia yang telah menyetujui akan langsung memproses dan menyediakan barang maupun 
jasa yang dibutihkan. Tahapan ini dapat mempersingkat waktu pembeli untuk menghubungi penyedia barang yang diinginkan.

3. Pemesanan Barang / Jasa

Secara otomatis sistem akan memesan barang sesuai dengan permintaan pembeli.

4. Penelusuran

e-Procurement mempunyai fasilitas pelacakan barang dan jasa yang dipesan secara langsung sehingga pembeli mengetahui secara langsung estimasi kedatangan barang.

5. Pembayaran

Sistem pembayaran akan muncul pada tampilan e-procurement yang dikirim dan langsung terhubung dengan laporan keuangan pembeli. Tahap ini bertujuan untuk memudahkan dalam mewujudkan laporan keuangan yang transparan dan dapat dipercaya.

\section{METODE}

Kajian ini menggunakan pendekatan kualitative. Pengumpulan data dengan cara observasi dengan melihat langsung kondisi di UPT LPSE Diskom info Kota Malang dan ULP Setda Kota Malang, wawancara dilakukan terhadap staf LPSE dan ULP Setda Kota Malang dan dokumentasi menggunakan peraturan perundangundangan berkaitan dengan pengadaan khususnya Perwali no 13 Tahun 2012 yang mengatur tentang pengadaan. Analisis data dengan cara reduksi data secara keseluruhan, penyajian data kajian serta penarikan kesimpulan dari hasil kajian. (Milles dan Huberman dikutip dari Rohidi, 2009;16)

\section{PELAKSANAAN E-PROCUREMENT DALAM PENGADAAN BARANG DAN JASA DI PEMERINTAH KOTA MALANG}

E-procurement sebagai sistem elektronik pengadaan dapat mempermudah dalam pelaksanaan kegiatan pengadaannya. Hal tersebut sesuai dengan pendapat Willem (2012:80) yaitu penggunaan e-procurement dalam pengadaan mampu mewujudkan efisiensi kerja pegawai dalam mekanisme pengadaan baik barang maupun jasa karena pengadaan tersebut dilakukan secara elektronik yaitu menggunakan jaringan internet. Pengadaan baik barang maupun jasa melalui $e$ proc diatur dalam PP No 70 Th 2012 Ttg Perubahan Kedua PP No 54 Th 2010 Ttg Pengadaan Barang/danJasa Pemerintah.
Kebijakan tersebut menjelaskan bahwa transaksi secara elektronik merupakan pengadaan baik barang maupun jasa yang dilakukan dengan menggunakan teknologi berdasarkan ketentuan perundang-undangan.

Pemerintah Kota Malang berupaya mewujudkan sarana dan prasarana dalam lingkup lingkungan pemerintahan yang lengkap dan berkualitas. Salah satu upayanya adalah melakukan pengadaan berbagai macam barang dan jasa. Saat ini pemerintah kota Malang setiap melakukan pengadaan berbagai barang dan jasa selalu dilakukan dengan cara elektronik melalui e-procurement. Dalam pelaksanaannya, Pemerintah Kota Malang berpedoman pada Perwali No. 13 Th 2012 ttg Tata/Cara Pengadaan Barang/dan Jasa Secara Elektronik.

Proses pengadaan baik barang maupun jasa di pemerintah kota malang dengan berbasis e-proc membutuhkan keterlibatan beberapa pihak yaitu:(PA)/(KPA), (PPK), ULP/Panitia, Pihak Ketiga/Penyedia dan LPSE

Mekanisme dan alur pelaksanaan kegiatan e-proc tersebut diantaranya:

1. Rancangan Pengadaan Barang -Jasa secara umum meliputi kegiatan:

a. Identifikasi kebutuhan barang serta jasa serta menetapkan rancangan anggaran yang diperlukan masing-masing instansi

b. Penetapan kebijakan tentang mekanisme proses pengadaan baik barang maupun jasa

c. Membuat KAK diantaranya berisi tentang kegiatan pengadaan, batas akhir waktu pelelangan, kriteria barang serta jasa dan nominal tarif barang serta jasa tersebut.

2. Persiapan Penentuan

a. PPK memberikan surat elektronik berupa kriteria teknis, dan perencanaan umum kontrak kepada ULP

b. ULP menyerahkan surat keputusan kepada LPSE tentang paket pemilihan untuk mendapatkan kode akses.

c. Pihak ketiga yaitu perusahaan penyedia barang maupun jasa melaksanakan proses registrasi pada aplikasi SPSE serta melakukan cek yang dilakukan oleh verifikator untuk memperoleh sandi.

d. LPSE menerima sandi dan menyimpan serta menerbitkan sandi tersebut pada keseluruhan nama yang ada pada surat keputusan sekaligus melakukan cek terhadap perusahaan penyedia barang dan jasa 
3. Proses Pemilihan

a. Penyusunan paket barang dan registrasi peserta ULP membuat paket pengadaan disertai informasi detail tentang paket dan sistem pengadaan, dan memasukkan soft copy yang diterbitkan oleh serta membuat jadwal pelaksanaan pemilihan pengadaan.

b. Pemberian Informasi

Proses pemberian informasi dilaksanakan dilaksanakan menggunakan sistem melalui aplikasi SPSE. Pada bagian ini, ULP diharuskan menjawab pertanyaan yang masuk yang dituliskan oleh perusahaan penyedia barang dan jasa. ULP dalam menjawab pertanyaan, secara teknis dilarang menjawab pertanyaan sekaligus pada akhir jadwal dengan cara mengumpulkan berbagai pertanyaan. Apabila pemberian informasi berakhir, ULP diberi kesempatan tambahan waktu 3 jam dalam merespon pertanyaan yang belum terjawab. Setelah itu ULP dapat memberikan informasi lanjutan dengan menunjuk seorang ahli yang telah ditetapkan oleh PPK.

c. Penyampaian kualifikasi

Data kualifikasi disampaikan melalui formulir elektronik pada aplikasi LPSE. Pada saat prakualifikasi, ULP meminta kepada perusahaan penyedia barang dan jasa untuk melengkapi formulir tersebut. Data kualifikasi tersebut berisi tentang persetujuan sebagai berikut:

1) Perusahaan penyedia barang tidak dalam pengawasan kasus hukum dan kegiatan usahanya tidak dalam kondisi bangkrut

2) Organisasi pengurus beserta badan usahanya tidak dalam kondisi masuk daftar hitam (Black List).

3) Kebenaran data isian dan kesanggupan perusahaan jika dikemudian hari terdapat informasi atau hal yang tidak benar maka perusahaan bersedia untuk dikenakan sanksi, baik sanksi administrasi, daftar hitam, kasus pidana dan perdata.

d. Penyampaian tawaran harga

Perusahaan penyedia baik barang maupun jasa mengirimkan berkas penawarannya yang diawali dengan cara melakukan pembuatan sandi melalui Apendo. ULP wajib memberikan alasan apabila terdapat perubahan jadwal tahap penyampaian penawaran.

e. Evaluasi

Pada mekanismeini ULP mendownload dan melakukan pemrosesan berkas tawaran dengan memanfaatkan Appendo Panitia. Proses evaluasi adminstrasi dan pengecekan harga dilakukan satu persatu secara manual dan hasil evaluasi di input ke dalam aplikasi SPSE. Aplikasi SPSE secara otomatis akan mengirimkan notifikasi kepada pemenang pemilihan dan mengikuti proses lebih lanjut yang pelaksanaannya di luar SPSE.

f. Sanggahan

Peserta lelang diberikan kesempatan 1 kali untuk memberikan sanggahan kepada ULP dengan menggunakan aplikasi SPSE kemudian ULP menjawab sanggahan peserta lelang dalam waktu yang sudah ditentukan.

g. Surat penunjukan penyedia barang dan jasa Pada tahap ini PPK membuat surat berupa penunjukan perusahaan penyedia barang serta jasa yang dikirimkan kepada perusahana melalui SPSE

h. Tanda tangan kontrak

PPK bersama pemenang proses pelelangan melakukan tanda tangan kontrak yang disertai dengan pengumpulan dokumen. PPK menginput semua informasi tentang kontrak dalam aplikasi SPSE sehingga dapat dilihat oleh siapapun.

\section{EFEKTIVITAS PELAKSANAAN E-PRO- CUREMENT DALAM PENGADAAN BARANG DAN JASA DI PEMERINTAH KOTA MALANG}

Pelaksanaan E-Proc di pemerintah kota Malang diatur dalam Perwali No 13 Tahun 2012. Didalam Peraturan tersebut memuat dasar pelaksanaan pengadaan baik barang maupun jasa pemerintah berbasis system di lingkup pemerintah daerah. Hal ini bertujuan untuk mewujudkan efisiensi, efektivitas serta transparansi dalam pengadaan di pemerintah kota Malang. Pelaksanaan E-Proc di pemerintah kota Malang dilakukan oleh UPT LPSE Diskominfo Kota Malang. UPT LPSE merupakan pelaksana yang memfasilitasi ULP/panitia pengadaan pada proses pengadaan baik barang maupun jasa di pemerintah 
kota Malang. Pengadaan Barang serta jasa dilakukan dengan berbasis sistem meliputi kriteria barang, kriteria pekerjaan konstruksian, kriteria jasa dan ahli konsultansi serta jasa lainnya berdasarkan dengan kebutuhan masing-masing OPD.

E-Procurement di pemerintah Kota Malang dilaksanakan melalui aplikasi SPSE yang dikembangkan oleh Lembaga Kebijakan Pengadaan Barang-Jasa Pemerintah (LKPP). Semua pihak yang berhubungan dengan E-Procurement dituntut untuk menaati aturan yang berlaku diantaranya menjaga kerahasiaan kode akses dan penyalagunaan data E-Procurement serta tidak melakukan pengaturan untuk memenangkan pihak tertentu dengan cara kolusi dan nepotisme. Selain itu juga semua pihak tidak diperkenakna untuk mengacaukan system E-Procurement dan memanipulasi data yang dapat mempengaruhi pelaksaanaan pengadaan barang dan jasa.

Menurut Mahmudi (2010: 57) prinsip manajemen aset daerah harus diperhatikaan dalam mekanisme pengadaan. Prinsip manajemen tersebut dilakukan oleh Pemerintah Daerah yaitu dengan cara melakukan manajemen aset dimulai tahap perencanaan sampai penghapusan dan keseluruhan tahap tersebut harus tercatat dengan baik. Berdasarkan pendapat tersebut maka dalam proses pengadaan baik barang maupun jasa dengan menggunakan $e$-Proc seyogyanya dapat dilakukan dengan praktis dan tertib, sehingga penggunaan sistem dapat membuat pelaksanaan menjadi lebih mudah dan maksimal.

Pemerintah Kota Malang dalam melaksanakan pengadaan menggunakan prinsipprinsip berikut:

1. Efisien

Penggunaan dana dan fasilitas yang secukupnya dalam pelaksanaan penggadaan berbagai barang dan dalam jangka waktu yang singkat untuk mencapai sasaran yang ditetapkan serta dapat dipertanggungjawabkan.

2. Efektif

Pengadaan baik barang maupun jasa disesuaikan dengan kebutuhan lembaga yang telah disusun dan ditetapkan sehingga memberikan keuntungan dan manfaat yang besar sesuai dengan harapan perencanaan yang sudah ditetapkan.

3. Kompetitif

Pelaksanaan pengadaan baik barang maupun jasa dilaksanakan melalui seleksi dan persaingan yang sehat antar perusahaan penyedia berdasar pada syarat dan ketentuan yang telah ditentukan

4. Transparan

Semua informasi berkaitan tentang proses pengadaan yang diawali dengan pendaftaran perusahaan penyedia barang sampai pada penetapan pemenang sifatnya terbuka serta dapat diakses oleh semua orang

5. Bertanggungjawab

Pelaksanaan pengadaan dapat mencapai tujuan baik fisik, keuangan, manfaat serta dapat dipertanggungjawabkan berdasarkan peraturan yang berlaku.

Keseluruhan komponen yang terlibat dalam proses E-Proc di pemerintah Kota Malang adalah PA/KPA, PPK, ULP, Perusahaan Penyedia, LPSE dan pihak ketiga (badan/perusahaan). Menurut Vaidya and Callender (2006) Proyek $e$ procurement mencakup keterlibatan sejumlah besar pemangku kepentingan internal dan eksternal (yaitu, pembeli, pengguna akhir, pemasok, penyedia layanan, konsultan, penjual perorangan, dan sponsor), pentingnya keterlibatan pemangku kepentingan tidak dapat di abaikan.Jenis pemilihan perusahaan penyedia baik barang maupun jasa terdiri atas:

1. Pemilihan penyediaan baik barang maupun jasa melalui proses lelang umum dan sederhana.

2. Pemilihan perusahaan penyedia konstruksi dilaksanakan dengan proses lelang umum dan pilihan langsung

3. Pemilihan perusahaan penyedia jasa konsultansi dilaksanakan dengan cara proses lelang umum dan sederhana

Teknis pelaksanaan E-Procurement meliputi rancangan umum baik pengadaan barang maupun jasa, proses pra pemilihan, dan proses pelaksanaan yaitu penyusunan paket dan pendaftaran baik barang maupun jasa, proses pemberian informasi, proses memasukkan kualifikasi, proses memasukkan penawaran, proses awal penawaran, proses penyanggahan, surat penunjukkan perusahaan penyedia dan proses penandatanganan kontrak. Dalam pelaksanaannnya LPSE mengundang OPD, asosiasi diantaranya gapensi, gapeknas, pihak ketiga penyedia barang maupun jasa lainnya dalam rangka pengarahan terkait dengan penyeleng-garaan e-procurement yang dikemas dalam kegiatan bimbingan teknis yang biasanya diselenggarakan di awal tahun. 
Pelaksanaan e-procurement di kota malang diselenggarakan oleh LPSE dan ULP. LPSE kota Malang sendiri berjalan sejak tahun 2012. Sebelumnya pelaksanaan pengadaan barang maupun jasa di kota Malang dilakukan secara konvensional. Dalam pelaksanaan e-procurement LPSE selalu bekerja sama dengan ULP, mengingat LPSE sebagai penyedia layanan e-procurement dan ULP sebagai panitia pelaksana pelelangan. Staff LPSE Kota Malang jumlahnya relative sedikit, namun hal tersebut tidak menghambat jalannya pelaksanaan e-procurement karena LPSE hanya memfasilitasi jaringan yang digunakan untuk proses pelelangan secara elektronik. Selain itu juga melaporkan kepada LKPP apabila ditemukan permasalahan jaringan atau system yang ada. System yang digunakan oleh LPSE adalah SPSE V.4. System yang digunakan tersebut selalu diperbarui sesuai dengan ketentuan dari LKPP.

ULP Setda Kota Malang mempunyai tugas sebagai panitia pelelangan yang mengakomodir kebutuhan barang dan jasa di masing-masing OPD di pemerintah Kota Malang. Namun pengadaan yang difasilitasi oleh ULP sendiri mempunyai beberapa kriteria diantaranya jumlah nominal barang maupun jasa yang dilelang. Untuk pengadaan barang jumlah nominal yang difasilitasi oleh ULP Setda Kota Malang adalah diatas 200 juta, sedangkan jasa konsultansi jumlah nominalnya lebih dari 50 juta. Untuk jasa jumlah nominalnya diatas 200 juta, sedangkan penunjukan jumlah nominalnya lebih dari 200 juta. Hal tersebut mengacu pada Perpres No. 54 th 2007. Apabila pengadaan barang dan jasa jumlah nominalnya dibawah kriteria, maka pengadaan dikembalikan kepada masing-masing OPD. System yang digunakan dalam proses e-procurement adalah dengan menggunakan "sibaja". System ini sudah berjalan 2 tahun dan produk pemerintah Kota Malang.Sedangkan informasi pengadaan barang dan jasa dapat diakses di aplikasi sirup/lkpp.go.id. Aplikasi tersebut milik LKPP yang didalamnnya termuat system informasi rencana umum pengadaan.SIRUP terdapat pada laman inaproc.lkpp.go.id/sirup.

Adanya e-proc di pemerintah Kota Malang memudahkan bagi setiap OPD dalam melakukan proses pengadaan barang maupun jasa. Efektivitas, efisiensi dan transparansi sangat terlihat dalam pelaksanaan e-proc di pemerintah Kota Malang. Jumlah e-proc di kota Malang pada tahun 2015 sebanyak 386 paket, sedangkan pada tahun 2016 sebanyak 229 paket. Meskipun demikian dalam pelaksanaan e-proc di pemerintah Kota Malang terdapat beberapa hambatan. Hambatan tersebut tentunya menuntut penyelenggara e-procurement untuk melakukan upaya dalam mengatasi hambatan sehingga apabila hambatan tersebut dapat diatasi maka pelaksanaan e-procurement akan semakin baik.

E-procurement berdampak positif pada proses pengadaan baik barang maupun jasa yaitu terjadinya efisiensi nominal harga barang, durasi proses pembelian barang, mekanisme penagihan, dan pembayaran tagihan serta efisiensi biaya administrasi dan waktu dari keseluruhan proses pengadaan baik barang maupun jasa. Selain itu dengan menggunakan e-procurement, transparansi dan keterbukaan akan cenderung terwujud serta menghilangkan budaya tidak sehat yang mampu mengurangi terjadinya penyimpangan karena di dalam prosesnya menjadikan kecilnya peluang pertemuan antara perusahaan penyedia barang maupun jasa dengan panitia pelelangan.

\section{HAMBATAN PELAKSANAAN E-PRO- CUREMENT DALAM PENGADAAN BARANG DAN JASA DI PEMERINTAH KOTA MALANG}

Hambatan pelaksanaan e-proc dalam pengadaan baik barang maupun jasa di pemerintah kota malang terbagi menjadi 2 (dua) yaitu yang terdapat pada UPT LPSE Dinas Komunikasi dan Informasi Kota Malang dan pada ULP Setda Kota Malang. Hambatan yang terdapat pada UPT LPSE Diskominfo Kota Malang adalah ketika terdapat masalah teknis terkait dengan jaringan e-procurement tidak dapat diatasi secara langsung oleh LPSE sendiri karena jaringan tersebut berpusat di LKPP yang ada di Jakarta sehingga penanganan permasalahan teknis tersebut menunggu respon dari pusat sedangkan LPSE hanya sekedar melaporkan permasalahannya saja. Hal ini tentunya sangat menghambat pelaksanaan e-procurement karena apabila terapat permasalahan berkaitan dengan jaringan maka akan memakan waktu cukup lama mengingat permasalahan yang diatasi oleh LKPP tersebut lingkupnya nasional tidak hanya pemerintah kota Malang saja namun terdiri dari 514 kabupaten/kota di seluruh Indonesia. 
Hambatan yang terdapat pada ULP Setda Kota Malang yaitu pembagian tugas dalam struktur organisasi. Pembagian tugas pada ULP Setda Kota Malang ditemukan adanya rangkap jabatan maupun tugas. Temuan tersebut yaitu adanya rangkap jabatan subag TU dengan ex officio sekretaris. Hal ini memunculkan beban kerja yang lebih sehingga mengganggu pelaksanaan $e$ procurement oleh UPT ULP Setda Kota Malang yang dalam hal ini sebagai panitia pengadaan karena secara sederhana dapat diartikan satu orang menangani dua tugas pokok dan fungsi yaitu sebagai subag TU ULP dan sebagai sekretaris ULP.Hambatan yang selanjutnya adalah sumber daya manusia di ULP Setda Kota Malang yang kurang mendukung pelaksanaan e-procurement mengingat bidang keahlian staff di ULP Setda Kota Malang bermacam-macam namun tidak ada bidang keahlian yang sesuai dengan kebutuhan $e$ procurement. Padahal summber daya manusia merupakan unser terpenting dalam keberhasilan sebuah pemerintahan utamanya berkaitan dengan pelayanan publik. Sumber daya manusia menjadi perencana, pemikir dan penggerak dalam mencapai tujuan pemerintah dalam hal ini berkaitan dengan LPSE.Sumberdaya manusia berkaitan juga dengan sistem informasi manajemen. Menurut Cushing dikutip oleh Jogiyanto (2005: 14) mengenai System Informasi Managemen (SIM) adalah organisasi baik publik maupun swasta yang berada di dalamnya sekumpulan dari orang beserta sumber daya yang melekat di dalamnya yang bertugas untuk menemukan dan memproduksi data untuk menghasilkan data sebagai bahan informasi utuh yang bermanfaat untuk semua jajaran dalam sebuah managemen di dalam lingkup kegiatan perencanaan dan evaluasi.Selain itu akibat dari kurangnya sumber daya manusia juga berdampak pada perbedaan pemahaman ketentuan, aturanaturan dan pasal-pasal terkait dengan e-procurement. Rendahnya kualitas kinerja pelaksanaan pada era desentralisasi dalam kebijakan otonomi daerah salah satunya dipengaruhi oleh minimnya pegawai yang memiliki kompetensi pendidikan dan kemampuan yang sesuai dengan bidang pekerjaannya(Habibi, 2016)

Menurut Al Hakim. 2016 Upaya pemerintah dalam meningkatkan sumber daya manusia yang lebih berkualitas dapat dilakukan dengan berbagai strategi salah satunya masing-masing organisasi harus mengevaluasi dan mendesai kembali perencanaan organisasinya dan melakukan pengelolaan manajemen kinerja yang dalam hal ini berusaha untuk mengusahakan agar sumber daya manusia pada masing-masing organisasi mampu bekerja sama untuk mencapai tujuan organisasi tersebut.

Hambatan yang selanjutnya adalah prasarana yang tidak mendukung. Perbandingan jumlah staf, pimpinan dan tamu (penyedia barang dan jasa) dengan ruangan tidak sesuai. Situasi kantor yang penuh dan sesak sangat terlihat di ULP Setda Kota Malang. Sering juga ketika penyedia barang dan jasa berkumpul menjadi satu di kantor ULP Setda Kota Malang di tempatkan di ruangan pimpinan. Hal ini tentu mengganggu kinerja pegawai yang semestinya dapat bekerja dengan baik, namun akhirnya kurang maksimal karena kondisi ruangan yang tidak representatif sehingga tentu berpengaruh terhadap penyelesaian tugas-tugas. Menurut Indri 2019, keberhasilan suatu organisasi salah satunya dipengaruhi sarana dan prasarana. Lingkungan organisasi harus menyediakan sarana dan prasarana yang nyaman untuk digunakan oleh pegawai sehingga menunjang kinerja pegawai tersebut dalam mencapai tujuan organisasi.

\section{SIMPULAN}

E-procurement adalah salah satu terobosan pemerintah dalam pembelian baik barang maupun jasa. Sebelumnnya pengadaan baik barang maupun jasa di lingkungan pemerintahan dilakukan secara konvensional. Hal ini tentunya memunculkan permasalahan yaitu kurang efisien dari sisi pembiayaan,waktu dan dikhawatirkan berpotensi menimbulkan berbagai bentuk praktek KKN salah satunya kompromi dalam hal pengadaan baik barang maupun jasa. E-proc menjadikan proses pengadaan baik barang maupun jasa menjadi lebih efektif, efisien dan transparan yaitu prosesnya pengadaannya lebih cepat, tepat dan transparan. E-proc di Kota Malang di fasilitasi oleh UPT LPSE Diskominfo Kota Malang dan ULP Setda Kota Malang. UPT LPSE Diskominfo Kota Malang bertindak sebagai penyedia fasilitas dan jaringan e-procurement sedangkan ULP Setda Kota Malang bertugas sebagai panitia pelaksana pelelangan yang mengakomodir pengajuan barang maupun jasa setiap OPD di pemerintah Kota Malang. Pelaksanaan e-procurement di Kota Malang berjalan efektif terbukti dari banyaknya paket yang diproses dalam e-procurement berjalan dengan 
lancer. Sistem pelelangannya juga sangat transparan terbukti dengan siapapun peserta tender dapat mengikuti langsung proses tendernya. Pelaksanaan e-procurement mengalami beberapa hambatan, yaitu penanganan dalam permasalahan sistem yang cenderung prosedural khususnya ketika terjadi permasalahan berkaitan dengan jaringan yang harus menunggu perbaikan dari LKPP sehingga memperlambat proses tendering. Selain itu rangkap jabatan juga terjadi di ULP Setda

\section{DAFTAR RUJUKAN}

Al Hakim, S., Habibi, M. M., \& Sudirman, S. (2016). Implementasi Kebijakan

Remunerasi dalam Meningkatkan Kinerja Pegawai Negeri Sipil (PNS) di Fakultas Ilmu Sosial Universitas Negeri Malang. Jurnal Ilmiah Administrasi Publik, 2(3).

Habibi, M. M. (2016). Analisis Pelaksanaan Desentralisasi dalam Otonomi Daerah Kota/Kabupaten. Jurnal Ilmiah Pendidikan Pancasila dan Kewarganegaraan, 28(2).

Hasniati, 2006, Kebijakan Pengembangan Electronic Government : Sebuah Upaya Peningkatan Kualitas Pelayanan Publik di Era Otonomi Daerah, Visi Jurnal Ilmu Administrasi, Fisip Universitas Hasanuddin, Vol. VII, No.2, September 2006.

Lembaga Kebijakan Pengadaan Barang/Jasa Pemerintah (LKPP). Tentang E-Procurement, diakses 25 Januari 2017 dari http:// eproc.lkpp.go.id/goto/tentang-e-procure$\underline{\text { ment }}$

Marwansyah. 2010. Manajemen Sumber Daya Manusia edisi kedua. Bandung. Alfabeta.

Minogue, Martin, artikel "The Management of Public Change : from 'Old Public Administration' to 'New Public Management", dalam "Law \& Governance" Issue I, British Council Briefing.

Mulyawan, Budi. 2009. Pengaruh Pelaksanaan Good Governance terhadap kinerja Organisai. Universitas Sumatera Utara

Neupane, Arjun dkk. 2014. An Empirical Evaluation of the Potential of Public E-Procurement to Reduce Corruption. Australasian Journal of Information Systems Volume 18 Number 22014 21-44.
Kota Malang dikarenakan kurangnya pegawai sehingga menimbulkan beban kerja yang lebih. Selain itu juga sumber daya manusia berupa tidak adanya kualifikasi staf yang mempunyai kompetensi menangani pengadaan barang maupun jasa secara online, selain itu prasarana juga menjadi faktor penghambat dalam pelaksanaan $e$ procurement khusunya berkaitan dengan kondisi kantor yang tidak representatif.

Nugraha, Aldino Septa. 2012. Penerapan E-Procurement di Instansi Pemerintah Berdasarkan Peraturan Presiden Nomor 54 Tahun 2010 Tentang Pengadaan Barang/ Jasa.

Republik Indonesia. 2003. Pedoman Pelaksanaan Pengadaan Barang/Jasa Pemerintah, Keputusan Presiden No. 80 Tahun 2003

Republik Indonesia. 2005. Peraturan Presiden No. 32 Tentang Perubahan Kedua Atas Keputusan Presiden No. 80 Tahun 2003 Tentang Pedoman Pelaksanaan Pengadaan Barang/Jasa Pemerintah Tahun 2005.

Republik Indonesia. 2010. Peraturan Presiden No. 54 Tahun 2010 Tentang Pengadaan Barang/ Jasa Pemerintah.

Republik Indonesia. 2005. Peraturan Presiden Republik Indonesia No. 70 Tahun 2005 Tentang Perubahan Ketiga Atas Keputusan Presiden No. 80 Tahun 2003 Tentang Pedoman Pelaksanaan Pengadaan Barang/ Jasa Pemerintah.

Republik Indonesia. 2012.Peraturan Walikota Malang Nomor 13 Tahun 2012 tentang Tata Cara Pengadaan Barang/ Jasa Secara Elektronik

Rohidi, Tjetjep Rohendi. (1992) Analisis Data Kualitatif : Buku Sumber Metodemetode Baru (Matthew B. Miles dan A. Michael Huberman). Jakarta, Universitas Indonesia.

Selamat, Melani Dwiyanti. 2013. Penerapan Good Governance Dalam Penyelenggaraan Pemerintahan Daerah.

Sinambela, L.P.Teori, Kebijakan dan Implementasi, Reformasi Pelayanan Publik, Edisi Mei 2006. 
Solihin, Dadang. 2007. Indikator Governance dan Penerapannya dalam Mewujudkan Demokratisasi di Indonesia. Bandung: BAPPENAS.

Susanti, Gita, 2006, E-Government dalam Pelayanan Publik, Visi Jurnal Ilmu Administrasi, Fisip Universitas Hasanuddin, Vol. VII, No.2, September 2006.

Sutedi, Adrian. 2014 Aspek Hukum Pengadaan Barang dan Jasa dan BerbagaiBarang/Jasa Secara ElektronikSinar Grafika: Makassar Turban, Efraim dkk. 2004. Electronic Commerce: A Managerial Perspective. USA: Prentice Hall.
Udoyono, Kodar, Februari 2012, "E-Procurement dalam Pengadaan Barang dan Jasa untuk Mewujudkan Akuntabilitas di Kota Yogyakarta". Volume 3, No.1, http:// jsp.umy.ac.id/index.php?option=com phocadownload \&view $=$ category $\& d$ ownload=39:e-procurement-dalampenga d a a n-barang-d a n-jas a untukmewujudkan akuntabilitas-di-kotayogyakarta- $\&$ id $=4$ : volume-3-nomor-1februari-2012\&Itemid=14, 9 Februari 2015.

Vaidya, Kishor and Callender, Guy. 2006. Critical Factors That Influence E-Procurement Implementation Success In The Public Sector. Journal Of Public Procurement, Volume 6, Issues 1 \& 3, 70-99. 